\title{
Ryegrass-based diet and barley supplementation: Partition of nitrogenous nutrients among splanchnic tissues and hind limb in finishing lambs ${ }^{1}$
}

\author{
I. Savary-Auzeloux*2, L. Majdoub*, N. Le Floc'h†, and I. Ortigues-Marty* \\ *Unité de Recherches sur les Herbivores, Equipe Nutriments et Métabolismes, INRA Clermont Ferrand-Theix, \\ 63122 St. Genès Champanelle, France and †Unité Mixte de Recherche sur le Veau et le Porc, \\ INRA-ENSAR St. Gilles, 35590 St. Gilles, France
}

\begin{abstract}
Splanchnic metabolism of nitrogenous nutrients and their uptake by the hind limb were studied in finishing lambs receiving ryegrass harvested at grazing stage with or without barley supplementation. Six multicatheterized lambs $(40.2 \pm 1.5 \mathrm{~kg})$ were fed with frozen ryegrass (RG) at $690 \mathrm{~kJ}$ of ME intake $(\mathrm{MEI}) \cdot \mathrm{d}^{-1} \cdot \mathrm{BW}^{-0.75}$ and $20.8 \mathrm{~g}$ of $\mathrm{N}$ intake $(\mathrm{NI}) / \mathrm{d}$ successively without and with barley supplementation (RG + B), according to a crossover design. Barley supplementation represented $21 \%$ of DM intake and increased the MEI and the NI by 32 and $24 \%$ respectively, $(P<0.01)$. In the ruminal fluid, barley increased acetate and butyrate concentrations by 21.2 and $49.6 \%$, respectively $(P<$ 0.04 ), without any effect on the ammonia concentration. Consequently, the net portal appearance (NPA) of ammonia was not modified, but the NPA of total amino acids (TAA; +38\%) and nonessential amino acids (NEAA; $+45 \%)$ was increased $(P<0.05)$ by barley supplementation. Taken individually, the NPA of the essential amino acids (EAA) was increased for isoleucine $(+32 \% ; P<0.05)$, threonine $(+151 \% ; P<0.03)$, and lysine $(+26 \% ; P<0.06)$, with no effect for the other EAA. In contrast to what was observed at the PDV level, no
\end{abstract}

significant alteration in the net hepatic amino acid flux was observed for TAA, EAA, NEAA, branched-chain amino acids (BCAA), urea, and ammonia after barley supplementation, showing a relatively minor role of the liver in the regulation of the supply of amino acids to the peripheral tissues. However, taken individually, the net hepatic uptake of some NEAA involved in gluconeogenesis and/or ureagenesis was altered with barley supplementation: the alanine uptake was increased by $44 \%$ $(P<0.05)$, aspartate + asparagine (asx) uptake was decreased by $18 \%(P<0.01)$, and glutamate + glutamine (glx) release tended $(P<0.10)$ to be increased by $208 \%$. With barley supplementation, NI increased by $5 \mathrm{~g}$ of $\mathrm{N} / \mathrm{d}$, and net splanchnic release increased by $4.63 \mathrm{~g}$ of N/d. Consequently, the additional dietary N supply (together with energy supply) was nearly exclusively available to peripheral tissues as AA-N ( $\mathrm{N}$ as amino acids), but no strong effect of this additional supply of AA to the hind limb could be demonstrated in terms of net AA hind limb fluxes. Consequently, barley supplementation of a ryegrass-based diet increased the net AA release by the splanchnic tissues, with little effect on the AA net uptake by the peripheral tissues.

Key Words: Amino Acids, Barley, Hind Limb, Liver, Lolium, Portal Vein

(C)2003 American Society of Animal Science. All rights reserved.

J. Anim. Sci. 2003. 81:3160-3173

\section{Introduction}

In European countries, consumers show a growing interest for meat produced from grazing ruminants, which is considered to be more natural than that ob-

\footnotetext{
${ }^{1}$ The authors express their deep appreciation to J. Lefaivre and D. Durand for their surgical expertise, to C. Leoty and R. Souchet for their excellent care of the animals, to A. Thomas and C. Cossoul for their excellent technical assistance, and to Y. Colleaux for amino acid analysis.

${ }^{2}$ Correspondence-phone: (33) 4736247 32; fax: (33) (0)4 7362 46 39; E-mail: savary@clermont.inra.fr.

Received February 11, 2003.

Accepted August 19, 2003.
}

tained from grain-fed animals (Geay et al., 2001). However, the animals fed forages or fresh grass show a lower growth rate and a lighter carcass, both closely linked to a less-efficient $\mathrm{N}$ metabolism (MacRae et al., 1997; Krehbiel et al., 1998). Ruminants present a low efficiency in the conversion of dietary proteins into muscle proteins in comparison to nonruminant (Wessels and Titgemeyer, 1997), and the forage-fed ruminants present an even lower conversion efficiency and a lower intake capacity (INRA, 1978). Consequently, to improve the growth of animals fed fresh forages, a concentrate supplementation is often applied.

This additional supply of $\mathrm{N}$ is utilized by the gastrointestinal tract (GIT) and the liver before reaching the economically valuable tissues, such as muscle. The GIT 
and liver have an impact on the amount and the profile of the amino acids supplied to the peripheral tissues (Lapierre et al., 2000). When the AA and energy supplies are altered, their relative contribution in the utilization of AA is still a matter of debate because the partition of AA utilization between the splanchnic (GIT + liver) and the peripheral tissues depends on the type of diet offered to the animals, the level of intake, and the requirements of the animals. Consequently, when animals fed fresh grass are supplemented with barley, neither the contribution of the splanchnic tissues to the utilization of the additional $\mathrm{N}$ nor the efficiency with which this $\mathrm{N}$ can be utilized by the muscle are clearly known. The aim of this study was to characterize the profile of $\mathrm{N}$ nutrients appearing in the portal vein, their uptake by the liver, and the potential consequences on muscle metabolism in growing lambs fed fresh ryegrass and supplemented with barley. A companion paper (Majdoub et al., 2003) focused on the energy nutrients in the same study.

\section{Materials and Methods}

\section{Animals, Diets, and Treatments}

Six INRA 401 (Limousin $\times$ Ile de France $\times$ Romanov) intact male lambs were surgically equipped with a ruminal cannula (12 mm i.d.) and chronic blood catheters in the portal, hepatic, and external iliac veins as well as in a mesenteric artery, as described by Majdoub et al. (2003) and Savary-Auzeloux et al. (2003). Lambs were also fitted with two ultrasonic blood flow probes (Transonic Systems Inc., Ithaca, NY) in the portal vein (16 A) and an external iliac artery (3 R), and the blood flows were recorded using a flowmeter (T206, Transonic Systems Inc.). Animals were housed in individual stalls with ad libitum access to drinking water and tracemineralized lick salt $(0.75 \% \mathrm{Mn}, 0.15 \% \mathrm{Cu}, 0.90 \% \mathrm{Zn})$, and continuous lighting. During the entire experimental period, the catheters were rinsed with physiological saline containing diluted heparin (2,500 IU heparin/ $\mathrm{mL} \mathrm{NaCl} 0.9 \%$ ). The day before and the day of sampling, catheters were filled with saline sodium citrate buffer in order to avoid the effects of heparin on the metabolism of fatty acids.

After an adaptation period of $2 \mathrm{wk}$, lambs ( $7 \mathrm{mo}$ old, at an average experimental weight of $40.2 \pm 1.5 \mathrm{~kg}$ ) received two treatments: ryegrass $(\mathbf{R G})$ and ryegrass + barley $(\mathbf{R G}+\mathbf{B})$ according to a crossover design. Lambs were adapted to each treatment for 2 wk. For the RG treatment, animals were offered perennial ryegrass (first cut, fertilized at $80 \mathrm{~kg} \mathrm{~N} / \mathrm{ha}$ ), harvested at grazing stage (ear at $10 \mathrm{~cm}$ ), chopped in 5 -cm length, frozen at $-35^{\circ} \mathrm{C}$, and stored at $-15^{\circ} \mathrm{C}$, at an estimated level of $690 \mathrm{~kJ} \mathrm{ME} / \mathrm{kg}$ average metabolic $\mathrm{BW}\left(\mathrm{BW}^{0.75}\right)$, which represented approximately $75 \%$ of the ad libitum level, in 12 equal daily meals. For the $\mathrm{RG}+\mathrm{B}$ treatment, lambs were supplemented with $19 \mathrm{~g} / \mathrm{kg}$ of lamb BW $\mathrm{BW}^{0.75}$ of whole barley, which represented $26 \%$ of total estimated
ME. Ryegrass and barley ME contents were estimated at 11.59 and $13.25 \mathrm{MJ} / \mathrm{kg} \mathrm{DM}$, respectively (INRA, 1978). The weight of the lambs was not significantly altered by the treatments ( 40.1 and $40.3 \mathrm{~kg}$ for RG and RG + B animals, respectively, Majdoub et al., 2002). The DM and ME intake was $926 \mathrm{~g} / \mathrm{d}$ and $10.7 \mathrm{MJ} / \mathrm{d}$ for $\mathrm{RG}$ and $1,177 \mathrm{~g} / \mathrm{d}$ and $14.1 \mathrm{MJ} / \mathrm{d}$ for $\mathrm{RG}+\mathrm{B}$ animals, respectively (Majdoub et al, 2002). The $\mathrm{N}$ intake amounted to 20.8 and $25.8 \mathrm{~g}$ of N/d for RG and RG + $\mathrm{B}$ animals, respectively $(P<0.001)$. Consequently, the ratio of $\mathrm{N}$ to $\mathrm{ME}$ intake averaged 1.94 and $1.83 \mathrm{~g} \mathrm{~N} /$ $\mathrm{MJ}$ for $\mathrm{RG}$ and $\mathrm{RG}+\mathrm{B}$ animals, respectively. Hence, the barley supplementation increased the DM, ME, and $\mathrm{N}$ intakes by 27,32 and $24 \%$, respectively $(P<0.01$; Majdoub et al., 2002).

The experiment was conducted in a manner compatible with national legislation on animal care (Certificate of Authorization to Experiment on Living Animals, n004495, Ministry of Agriculture, France).

\section{Measurements}

Lambs were weighed twice weekly during the experimental period. Feed samples were taken daily and pooled for each animal and treatment period in order to determine chemical composition (DM, OM, CP, soluble N, crude fiber, and soluble sugar; Majdoub et al., 2002). The CP contents were analyzed according to Kjeldahl method (NF V18-100). The solubility of $\mathrm{N}$ was determined according to the Durand method (Vérité and Demarquilly, 1978). Crude fiber content was determined according to Weende method (NF V03-040) and soluble sugar content was determined using the Bertrand method (Halbwachs-Strich, 1969).

On the last day of treatment, blood flows in the portal vein and in the external iliac artery were continuously recorded over $4 \mathrm{~h}$ (over two feeding cycles, between 1100 and 1500). Hepatic arterial blood flow was estimated at $5.3 \%$ of the portal blood flow based on the reported contribution to hepatic blood flow (Barnes et al., 1986; Milano et al., 2000). A contribution of hepatic arterial blood flow to the hepatic blood flow of $5 \%$ has been measured by Barnes et al. (1986) in ovine using the microsphere method. To facilitate the interpretation of net iliac fluxes, which change depending on the position of the animal, visual observations were made of the behavior of the animals during this period, and blood sampling was carried out only on quietly standing animals. Eight sets of blood samples were taken from the portal vein, the hepatic vein, the external iliac vein, and from the mesenteric artery every $30 \mathrm{~min}$ and starting 15 min postprandially for individual chemical analysis. Blood $(2.5 \mathrm{~mL})$ was taken in tubes containing EDTA$\mathrm{K}(25 \mu \mathrm{L})$ as anticoagulant and aprotinine (1/10 vol/ vol) and was used for hematocrit determination prior to centrifugation at $4^{\circ} \mathrm{C}$. The resultant plasma was frozen at $-20^{\circ} \mathrm{C}$ for later analysis of $\mathrm{NH}_{3}$ (Bergmeyer, 1985 according to the Berthelot method), urea (KitS-1000, Biomérieux according to the Berthelot method), and 
AA. The AA concentrations were determined on pooled plasma samples. Plasma $(0.65 \mathrm{~mL})$ was deproteinized by adding $0.24 M$ sulfosalicylic acid (the sulfosalicylic acid solution contained $0.25 \mathrm{~m} M$ norvaline [internal standard]) and the mixture was centrifuged at 5,000 $\times$ $g$ for $15 \mathrm{~min}$. The $\mathrm{pH}$ of the supernatant was adjusted by adding a $0.5 \mathrm{M}$ citric acid solution buffered at $\mathrm{pH} 5$ with $\mathrm{LiOH}$. The samples were then analyzed by ion exchange chromatography, using ninhydrin as the colorimetric reagent (model LC 5001, Biotronik, Pusheim Banhof, Germany).

Three ruminal fluid samples were taken, one at each 30-min interval over one feeding cycle (between 1500 and 1700). For each sample, $\mathrm{pH}$ was immediately measured and $10 \mathrm{~mL}$ of filtered ruminal fluid was acidified with $1 \mathrm{~mL}$ of metaphosphoric acid (5\%, vol/vol) and frozen at $-20^{\circ} \mathrm{C}$ for subsequent analysis of VFA by GLC (Jouany, 1982) and ammonia (Van Eenaeme et al., 1969). Each sample was individually analyzed, and values were subsequently averaged per animal and per treatment.

\section{Calculations and Statistical Analysis}

Iliac blood flows of lambs in quietly standing state were calculated after elimination of values corresponding to agitated and lying states according to Isserty and Ortigues (1994). Net nutrient fluxes through the portaldrained viscera (PDV), the liver, and the hind limb were calculated as described by Katz and Bergman (1969) and Milano et al. (2000), using the average of the eight samples per vessel and plasma flow values averaged over time. Metabolite net portal appearance (NPA) was calculated as follows: $\left(\mathrm{MET}_{\mathrm{PV}}-\mathrm{MET}_{\mathrm{A}}\right) \times$ $\mathrm{PFp}$, where $\mathrm{PFp}$ is the portal plasma flow and $\mathrm{MET}_{\mathrm{PV}}$ and $\mathrm{MET}_{\mathrm{A}}$ are the metabolite concentrations in the portal vein and the artery, respectively. Because the AA were assayed in the plasma, the blood flows were transformed into plasma flows using the average hematocrit. The net hepatic fluxes of AA, ammonia and urea were calculated as follows: $\left[\mathrm{MET}_{\mathrm{HV}} \times 1.053-\left(\mathrm{MET}_{\mathrm{VP}}+\mathrm{MET}_{\mathrm{A}}\right.\right.$ $\times 0.053)] \times \mathrm{PFp}$, where $\mathrm{MET}_{\mathrm{HV}}$ is the metabolite concentrations in the hepatic vein. Lastly, the net fluxes of AA, ammonia, and urea across the hind limb were calculated as follows: $\left(\mathrm{MET}_{\mathrm{I}}-\mathrm{MET}_{\mathrm{A}}\right) \times \mathrm{PF}_{\mathrm{I}}$, where $\mathrm{PF}_{\mathrm{I}}$ is the iliac plasma flow and $\mathrm{MET}_{\mathrm{I}}$ the metabolite concentrations in the iliac vein. A positive net flux corresponds to a net release, whereas a negative net flux corresponds to an uptake. The fractional extraction was calculated as the ratio of the net flux to the afferent flow to the tissue. Essential amino acids (EAA) included histidine, isoleucine, leucine, lysine, methionine, phenylalanine, threonine, and valine; nonessential amino acids (NEAA) included alanine, arginine, asparagine + aspartic acid, glutamic acid + glutamine, glycine, proline, serine, and tyrosine; and branched-chain amino acids (BCAA) included isoleucine, leucine, and valine. Total amino acids (TAA) were the sum of EAA and NEAA.
The potential maximal contribution of substrates (such as alanine or glycine) to hepatic glucose production was calculated assuming all carbons in substrates were converted into glucose carbon.

Because of the death of one lamb just at the beginning of the experiment, results were analyzed by ANOVA according to a crossover design, with animal, treatment, and period as main factors ( $\operatorname{Var}=\mu+\alpha$ animal $+\beta$ treatment $+\delta$ period $+\varepsilon$ ). Analysis was carried out using the GLM procedure of Statistica version 5.5 (Statsoft, Tulsa, OK). Differences were declared significant at $P$ $<0.05$ and tendencies were declared for $0.05<P<0.10$.

\section{Results}

Correct positioning of catheters and probes was checked at necropsy. At the splanchnic level, catheters of the five animals had remained functional during the experimental period. At the hind limb level, catheters were functional in three animals only.

\section{Intake and Ruminal Fermentation Measurements}

The contents of ryegrass in OM, crude fiber, and soluble sugars are detailed in a companion paper (Majdoub et al., 2002). The CP content of ryegrass was $14.1 \%$ on a DM basis, and the soluble $\mathrm{N}$ amounted to $26.3 \%$ of total N. The ryegrass DM content was measured daily and averaged $15.2 \%$.

In ruminal fluid, the VFA concentrations increased $(P<0.02)$ from 73.6 to $88.2 \mathrm{~m} M$ with barley, as a result of a significant rise in ruminal acetate and butyrate concentrations by 21.2 and $49.6 \%$, respectively $(P<$ $0.04)$. The alterations in the molar proportions of the VFA as well as the ruminal fluid $\mathrm{pH}$ are presented in a companion paper (Majdoub et al., 2002). Ammonia concentrations were not statistically modified by barley supplementation and averaged $7.36 \mathrm{mM}$.

\section{Blood/Plasma Flow and Amino Acid, Ammonia, and Urea Concentrations}

Blood and plasma flows in the portal vein increased after barley supplementation $(+11 \%, P<0.05$ and $+10 \%$, $P<0.06$ for blood and plasma flows, respectively, Table 1). Nevertheless, the blood and plasma flows in the external iliac artery were not significantly altered by barley supplementation. Hematocrit was stable across the sampling period and was not modified by treatment, averaging 0.27 .

The arterial concentrations of TAA averaged 2,960 $\mu M$ and were not altered by the barley supplementation (Table 1). The EAA and NEAA averaged 35.3 and $64.7 \%$ of the TAA, respectively, and were not altered by the treatment. Only BCAA arterial concentrations tended $(P<0.09)$ to be decreased by barley supplementation. This decrease could be attributed to a decrease $(P<$ 0.05 ) in valine arterial concentration (Table 2). The other AA arterial concentrations were not altered by 
Table 1. Effect of barley supplementation on blood and plasma flows, and nitrogenous nutrient concentrations in mesenteric artery, portal vein, hepatic vein, and external iliac vein in lambs fed frozen ryegrass

\begin{tabular}{|c|c|c|c|c|c|}
\hline \multirow[b]{2}{*}{ Item } & \multirow[b]{2}{*}{$\mathrm{n}$} & \multicolumn{2}{|c|}{ Treatments } & \multirow[b]{2}{*}{$\mathrm{SEM}^{\mathrm{c}}$} & \multirow[b]{2}{*}{ Probability } \\
\hline & & RG & $R G+B$ & & \\
\hline \multicolumn{6}{|c|}{ Blood flows, L/h } \\
\hline $\mathrm{P}$ & 5 & 113.02 & 125.62 & 3.21 & 0.05 \\
\hline I & 3 & 8.50 & 9.78 & 0.56 & 0.20 \\
\hline \multicolumn{6}{|c|}{ Plasma flows, L/h } \\
\hline $\mathrm{P}$ & 5 & 82.53 & 91.00 & 3.44 & 0.06 \\
\hline I & 3 & 6.11 & 6.94 & 0.33 & 0.16 \\
\hline \multicolumn{6}{|c|}{$\mathrm{TAA}, \mu M^{\mathrm{a}}$} \\
\hline $\mathrm{A}^{\mathrm{b}}$ & 5 & 3,058 & 2,861 & 92 & 0.30 \\
\hline $\mathrm{P}$ & 5 & 3,238 & 3,087 & 80 & 0.42 \\
\hline $\mathrm{H}$ & 5 & 3,064 & 2,961 & 86 & 0.62 \\
\hline I & 3 & 2,962 & 2,890 & 131 & 0.49 \\
\hline \multicolumn{6}{|c|}{$\mathrm{EAA}, \mu M$} \\
\hline $\mathrm{A}$ & 5 & 1,106 & 980 & 48 & 0.11 \\
\hline $\mathrm{P}$ & 5 & 1,204 & 1,096 & 41 & 0.15 \\
\hline $\mathrm{H}$ & 5 & 1,154 & 1,063 & 46 & 0.22 \\
\hline I & 3 & 1,024 & 953 & 69 & 0.46 \\
\hline \multicolumn{6}{|c|}{ NEAA, $\mu M$} \\
\hline $\mathrm{A}$ & 5 & 1,951 & 1,880 & 50 & 0.62 \\
\hline $\mathrm{P}$ & 5 & 2,034 & 1,991 & 46 & 0.83 \\
\hline $\mathrm{H}$ & 5 & 1,909 & 1,899 & 48 & 0.94 \\
\hline I & 3 & 1,938 & 1,937 & 66 & 0.56 \\
\hline \multicolumn{6}{|c|}{ BCAA, $\mu M$} \\
\hline A & 5 & 526 & 461 & 20 & 0.09 \\
\hline $\mathrm{P}$ & 5 & 578 & 519 & 18 & 0.12 \\
\hline $\mathrm{H}$ & 5 & 564 & 514 & 21 & 0.18 \\
\hline I & 3 & 471 & 447 & 21 & 0.35 \\
\hline \multicolumn{6}{|c|}{ Ammonia-N, $\mathrm{m} M$} \\
\hline $\mathrm{A}$ & 5 & 0.10 & 0.11 & 0.01 & 0.69 \\
\hline $\mathrm{P}$ & 5 & 0.25 & 0.24 & 0.02 & 0.87 \\
\hline $\mathrm{H}$ & 5 & 0.12 & 0.11 & 0.01 & 0.84 \\
\hline I & 3 & 0.13 & 0.14 & 0.01 & 0.56 \\
\hline \multicolumn{6}{|c|}{ Urea- $\mathrm{N}, \mathrm{m} M$} \\
\hline $\mathrm{A}$ & 5 & 7.17 & 6.45 & 0.50 & 0.44 \\
\hline $\mathrm{P}$ & 5 & 6.68 & 6.16 & 0.47 & 0.55 \\
\hline $\mathrm{H}$ & 5 & 7.10 & 6.50 & 0.51 & 0.49 \\
\hline I & 3 & 6.57 & 5.88 & 0.69 & 0.68 \\
\hline
\end{tabular}

${ }^{\text {aTAA }}=$ total amino acids $(\mathrm{AA}) ; \mathrm{EAA}=$ essential AA; NEAA = nonessential AA; $\mathrm{BCAA}=$ branched-chain AA.

${ }^{\mathrm{b}} \mathrm{A}=$ mesenteric artery, $\mathrm{P}=$ portal vein, $\mathrm{H}=$ hepatic vein, and $\mathrm{I}=$ external iliac vein.

${ }^{\mathrm{c}} \mathrm{SEM}=\sqrt{(\text { residual mean error of treatments error/n) }} . \mathrm{RG}=$ ryegrass; $\mathrm{RG}+\mathrm{B}=$ ryegrass + barley.

the treatment (exception made for citrulline: decreased by $11.7 \% ; P<0.05 ;$ Table 3 ). Ammonia-N and urea-N arterial concentrations were not altered by the treatment. The concentrations of AA in the other vessels followed the same pattern of change as that observed in the artery after barley supplementation.

Net Fluxes of Amino Acids, Urea, and Ammonia in the Portal-Drained Viscera

For the RG treatment, the NPA of $\mathrm{N}$ as ammonia and TAA represented 19 and $24 \%$ of total $\mathrm{N}$ intake respectively (Table 4). Among the TAA, the NPA of EAA, NEAA, and BCAA represented, respectively, 64, 36 , and $28 \%$ of the TAA NPA. A net transfer of urea from the arterial blood to the lumen of the gut was observed (66\% of the total $\mathrm{N}$ intake). Taken individually, all the EAA showed a net release in the portal vein. The NEAA were also globally released in the portal vein ( $+6.88 \mathrm{mmol} / \mathrm{h}$ for the RG animals) except for glutamate + glutamine (glx), and two minor AA (hydroxyproline and aminobutyric acid), which showed a negative net portal flux $(-1.29 \mathrm{mmol} / \mathrm{h}$ for glx; Table 5$)$.

The barley supplementation induced an increase in TAA $(+38 \%, P<0.05)$ and NEAA $(+45 \%, P<0.05)$ as well as a tendency for an increase in EAA $(+31 \%, P<$ $0.06)$ NPA but no effects on urea and ammonia. In barley-supplemented animals, the NPA of ammonia and TAA represented 15 and $33 \%$ of the ingested N, respectively. Taken individually, the NPA of the EAA was 
Table 2. Effect of barley supplementation on essential amino acids concentrations in mesenteric artery, portal vein, hepatic vein, and external iliac vein

in lambs fed frozen ryegrass

\begin{tabular}{|c|c|c|c|c|c|}
\hline \multirow[b]{2}{*}{ Amino acid } & \multirow[b]{2}{*}{$\mathrm{n}$} & \multicolumn{2}{|c|}{ Treatments } & \multirow[b]{2}{*}{$\mathrm{SEM}^{\mathrm{b}}$} & \multirow[b]{2}{*}{ Probability } \\
\hline & & RG & $R G+B$ & & \\
\hline \multicolumn{6}{|c|}{ Histidine, $\mu M$} \\
\hline $\mathrm{A}^{\mathrm{a}}$ & 5 & 58.0 & 52.4 & 3.4 & 0.43 \\
\hline $\mathrm{P}$ & 5 & 58.9 & 54.9 & 3.4 & 0.56 \\
\hline $\mathrm{H}$ & 5 & 55.9 & 54.3 & 3.4 & 0.85 \\
\hline I & 3 & 54.7 & 51.3 & 4.8 & 0.49 \\
\hline \multicolumn{6}{|c|}{ Isoleucine, $\mu M$} \\
\hline $\mathrm{A}$ & 5 & 126.8 & 119.8 & 3.3 & 0.33 \\
\hline $\mathrm{P}$ & 5 & 142.8 & 138.8 & 2.5 & 0.54 \\
\hline $\mathrm{H}$ & 5 & 139.5 & 137.5 & 3.6 & 0.74 \\
\hline I & 3 & 110.9 & 114.9 & 2.6 & 0.20 \\
\hline \multicolumn{6}{|l|}{ Leucine, $\mu M$} \\
\hline $\mathrm{A}$ & 5 & 143.6 & 122.3 & 6.7 & 0.12 \\
\hline $\mathrm{P}$ & 5 & 165.1 & 144.9 & 6.3 & 0.19 \\
\hline $\mathrm{H}$ & 5 & 159.6 & 141.4 & 7.3 & 0.23 \\
\hline I & 3 & 125.0 & 119.6 & 7.4 & 0.90 \\
\hline \multicolumn{6}{|l|}{ Lysine, $\mu M$} \\
\hline $\mathrm{A}$ & 5 & 183.2 & 182.0 & 13.7 & 0.88 \\
\hline $\mathrm{P}$ & 5 & 202.0 & 203.2 & 13.5 & 0.83 \\
\hline $\mathrm{H}$ & 5 & 195.5 & 196.3 & 14.0 & 0.89 \\
\hline I & 3 & 170.0 & 165.7 & 21.9 & 0.08 \\
\hline \multicolumn{6}{|c|}{ Methionine, $\mu M$} \\
\hline $\mathrm{A}$ & 5 & 30.4 & 27.5 & 1.7 & 0.41 \\
\hline $\mathrm{P}$ & 5 & 35.4 & 33.1 & 1.8 & 0.60 \\
\hline $\mathrm{H}$ & 5 & 31.9 & 30.8 & 1.5 & 0.94 \\
\hline I & 3 & 24.3 & 27.1 & 1.3 & 0.10 \\
\hline \multicolumn{6}{|c|}{ Phenylalanine, $\mu M$} \\
\hline $\mathrm{A}$ & 5 & 78.9 & 74.3 & 2.9 & 0.49 \\
\hline $\mathrm{P}$ & 5 & 92.7 & 87.1 & 3.2 & 0.39 \\
\hline $\mathrm{H}$ & 5 & 76.2 & 74.8 & 3.2 & 0.80 \\
\hline I & 3 & 74.6 & 74.4 & 4.0 & 0.89 \\
\hline \multicolumn{6}{|c|}{ Threonine, $\mu M$} \\
\hline $\mathrm{A}$ & 5 & 230.1 & 183.0 & 28.0 & 0.12 \\
\hline $\mathrm{P}$ & 5 & 236.6 & 198.4 & 25.1 & 0.17 \\
\hline $\mathrm{H}$ & 5 & 231.2 & 193.0 & 25.1 & 0.14 \\
\hline $\mathrm{I}$ & 3 & 229.7 & 187.7 & 42.4 & 0.56 \\
\hline \multicolumn{6}{|l|}{ Valine, $\mu M$} \\
\hline $\mathrm{A}$ & 5 & 255.3 & 218.9 & 11.2 & 0.05 \\
\hline $\mathrm{P}$ & 5 & 270.5 & 235.4 & 10.4 & 0.05 \\
\hline $\mathrm{H}$ & 5 & 264.6 & 234.6 & 11.2 & 0.07 \\
\hline I & 3 & 235.4 & 212.4 & 12.3 & 0.03 \\
\hline
\end{tabular}

${ }^{\mathrm{a}} \mathrm{A}=$ mesenteric artery, $\mathrm{P}=$ portal vein, $\mathrm{H}=$ hepatic vein, and $\mathrm{I}=$ external iliac vein.

${ }^{\mathrm{b}} \mathrm{SEM}=\sqrt{(\text { residual mean error of treatments error/n) }} . \mathrm{RG}=$ ryegrass; $\mathrm{RG}+\mathrm{B}=$ ryegrass + barley.

increased for isoleucine $(+32 \%, P<0.05)$, threonine $(+151 \%, P<0.03)$, and lysine $(+26 \%, P<0.06)$ with no effect for the other EAA (histidine, leucine, methionine, phenylalanine, and valine) (Table 6). The NPA of the NEAA followed the same pattern of change as the EAA because their NPA was either significantly increased by the barley supplementation (arginine, citrulline, glycine, hydroxyproline, ornithine, and taurine) or not affected (Table 5). Unlike the other NEAA, the NPA of glx was decreased in barley-supplemented animals $(-53 \%, P<0.05)$.
Net Fluxes of Amino Acids, Urea, and Ammonia in the Liver

For the RG animals, the net hepatic uptake of TAA represented $98 \%$ of the net portal release (Table 4 ). When EAA were considered, the net hepatic flux represented only $49 \%$ of the NPA. On the contrary for NEAA, the hepatic uptake was superior to the NPA of NEAA (6.88 $\mathrm{mmol} / \mathrm{h}$ for NPA and $-10.63 \mathrm{mmol} / \mathrm{h}$ for hepatic uptake). Taken individually, nearly each of the NEAA showed a net liver utilization (or no utilization), with 
Table 3. Effect of barley supplementation on nonessential amino acids concentrations in mesenteric artery, portal vein, hepatic vein, and external iliac vein in lambs fed frozen ryegrass

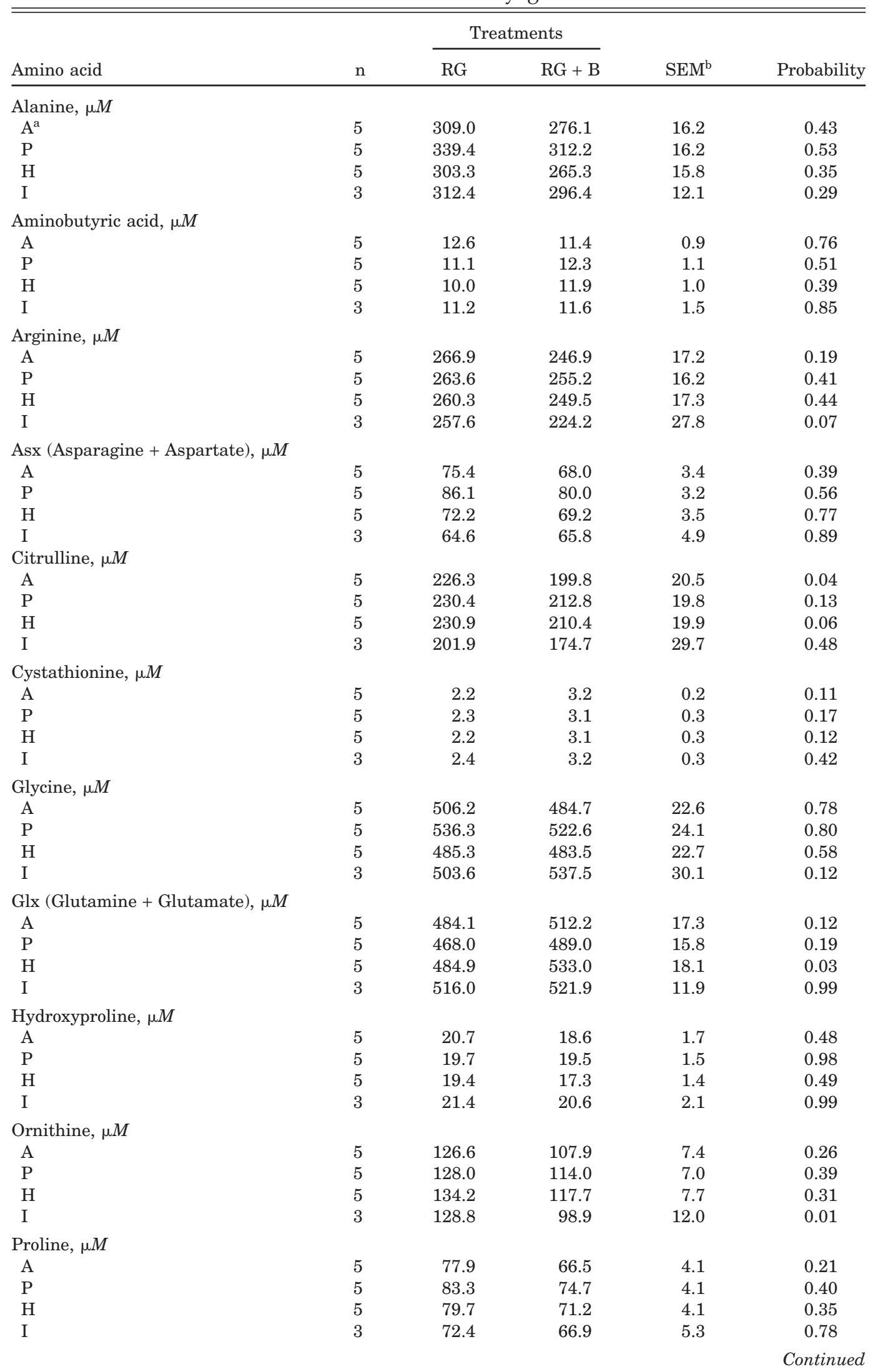


Table 3 Continued. Effect of barley supplementation on nonessential amino acids concentrations in mesenteric artery, portal vein, hepatic vein, and external iliac vein in lambs fed frozen ryegrass

\begin{tabular}{|c|c|c|c|c|c|}
\hline \multirow[b]{2}{*}{ Amino acid } & \multirow[b]{2}{*}{$\mathrm{n}$} & \multicolumn{2}{|c|}{ Treatments } & \multirow[b]{2}{*}{$\mathrm{SEM}^{\mathrm{b}}$} & \multirow[b]{2}{*}{ Probability } \\
\hline & & RG & $R G+B$ & & \\
\hline \multicolumn{6}{|l|}{ Serine, $\mu M$} \\
\hline $\mathrm{A}$ & 5 & 120.1 & 118.0 & 5.8 & 0.98 \\
\hline $\mathrm{P}$ & 5 & 135.8 & 137.3 & 4.8 & 0.58 \\
\hline $\mathrm{H}$ & 5 & 115.4 & 119.5 & 6.1 & 0.36 \\
\hline I & 3 & 104.5 & 110.8 & 7.8 & 0.35 \\
\hline \multicolumn{6}{|l|}{ Taurine, $\mu M$} \\
\hline $\mathrm{A}$ & 5 & 51.4 & 39.1 & 6.1 & 0.24 \\
\hline $\mathrm{P}$ & 5 & 53.6 & 44.9 & 6.0 & 0.42 \\
\hline $\mathrm{H}$ & 5 & 48.7 & 43.8 & 6.4 & 0.66 \\
\hline I & 3 & 45.7 & 37.6 & 9.9 & 0.07 \\
\hline \multicolumn{6}{|c|}{ Tyrosine, $\mu M$} \\
\hline $\mathrm{A}$ & 5 & 111.7 & 108.1 & 6.2 & 0.71 \\
\hline $\mathrm{P}$ & 5 & 121.4 & 119.8 & 5.9 & 0.85 \\
\hline $\mathrm{H}$ & 5 & 108.3 & 107.5 & 6.1 & 0.86 \\
\hline I & 3 & 106.8 & 113.0 & 9.7 & 0.60 \\
\hline
\end{tabular}

${ }^{\mathrm{a}} \mathrm{A}=$ mesenteric artery, $\mathrm{P}=$ portal vein, $\mathrm{H}=$ hepatic vein and $\mathrm{I}=$ external iliac vein.

${ }^{\mathrm{b}} \mathrm{SEM}=\sqrt{(\text { residual mean error of treatments error/n). }} \mathrm{RG}=$ ryegrass; $\mathrm{RG}+\mathrm{B}=$ ryegrass + barley.

fractional extraction ranging from $16 \%$ for aspartate + asparagine (asx) to $1.05 \%$ for hydroxyproline. Only glx and ornithine were released by the liver $(1.29 \mathrm{mmol} / \mathrm{h}$ and $0.55 \mathrm{mmol} / \mathrm{h}$ for glx and ornithine in RG animals, respectively). The majority of the ammonia appearing in the portal vein $(90.5 \%)$ was taken up by the liver. However, the proportion of urea- $\mathrm{N}$ that potentially originated from ammonia was low (34\%). Another $38 \%$ of the urea-N potentially arose from the NEAA. However, the origin of the remaining $28 \%$ is unknown.

With barley supplementation and contrary to what was observed at the PDV level, no treatment differences in net hepatic amino acid flux was observed for TAA, EAA, NEAA, and BCAA (Table 4). Similarly, urea and ammonia fluxes across the liver were not significantly altered. Taken individually, all the EAA liver net uptake was not affected by barley supplementation, with the exception of histidine, which showed a decreased $(P<0.02)$ net liver uptake $(-76 \%)$. Among the NEAA, the liver net uptake of alanine, asx, and glx were significantly or tended to be altered in the barley-supplemented animals (Table 5). The alanine uptake was increased by $44 \%(P<0.05)$, the asx uptake was decreased by $18 \%(P<0.00)$, and the glx release tended $(P<0.1)$ to be increased by $208 \%$.

Because no strong effect of the barley supplementation could be underlined at the hepatic level, the effects observed at the total splanchnic tissues (TSP) level for TAA, EAA, NEAA, BCAA (altogether or taken individually), ammonia-N, and urea-N were globally similar to those observed at the PDV level (Tables 4, 5, and 6).

Net Fluxes of Amino Acids

and Ammonia in the Hind Limb

The values obtained at the hind limb level should be taken cautiously because only three animals were used for the calculations of the net hind limb fluxes (the iliac catheters of the other two animals had lost patency). For the RG animals, the TAA were taken up $(-0.80$ $\mathrm{mmol} / \mathrm{h}$ ) at the hind limb level (primarily as EAA: -0.54 $\mathrm{mmol} / \mathrm{h}$ ). Taken individually, the net hind limb flux of each AA was negative or null ranging from $-0.14 \mathrm{mmol} /$ $\mathrm{h}$ for serine to $+0.03 \mathrm{mmol} / \mathrm{h}$ for glycine and glx. The net ammonia-N fluxes across the hind limb were slightly positive $(+0.08 \mathrm{mmol} / \mathrm{h})$, which indicated a net release.

No significant effects of barley supplementation on the hind limb net fluxes could be demonstrated for TAA, EAA, NEAA, BCAA, and ammonia. The effect of barley supplementation on net hind limb fluxes were only significant for a few NEAA such as asx $(P<0.03)$, Gly $(P$ $<0.00)$, and Tau $(P<0.02)$. For the EAA, only the Leu net hind limb flux was decreased $(P<0.04)$ by barley supplementation.

\section{Discussion}

The aim of this study was to investigate how an alteration of the $\mathrm{N}$ and energy supply in the rumen (with a barley supplementation) could alter the utilization of the $\mathrm{N}$ nutrients (AA, ammonia, and urea) by tissues and organs, such as the digestive tract, liver, and muscle. Indeed, a significant proportion of the AA taken up by the splanchnic tissues are used for purposes other than protein accretion in tissues, such as muscles. A better understanding of the nutrient partition between the different tissues and organs as well as the different metabolic routes followed by the nutrients within a tissue is of major importance to improve the diet recommendations to growing ruminants. Whether or not a simultaneous supplementation of $\mathrm{N}$ and energy (in comparison to energy or $\mathrm{N}$ supplemented alone) is more or less efficient in favoring growth will be discussed. 
Table 4. Effect of barley supplementation on splanchnic and hind limb net fluxes of nitrogenous nutrients in lambs fed frozen ryegrass

\begin{tabular}{|c|c|c|c|c|c|}
\hline \multirow[b]{2}{*}{ Item } & \multirow[b]{2}{*}{$\mathrm{n}$} & \multicolumn{2}{|c|}{ Treatments } & \multirow[b]{2}{*}{$\mathrm{SEM}^{\mathrm{c}}$} & \multirow[b]{2}{*}{ Probability } \\
\hline & & RG & $R G+B$ & & \\
\hline \multicolumn{6}{|c|}{$\mathrm{TAA}, \mathrm{mmol} / \mathrm{h}^{\mathrm{a}}$} \\
\hline $\mathrm{PDV}^{\mathrm{b}}$ & 5 & 14.82 & 20.42 & 1.98 & 0.05 \\
\hline Liver & 5 & -14.51 & -10.58 & 2.00 & 0.46 \\
\hline TSP & 5 & 0.31 & 9.84 & 2.12 & 0.07 \\
\hline $\mathrm{HL}$ & 3 & -0.80 & -0.72 & 0.20 & 0.93 \\
\hline \multicolumn{6}{|c|}{$\mathrm{EAA}, \mathrm{mmol} / \mathrm{h}$} \\
\hline PDV & 5 & 7.94 & 10.42 & 1.00 & 0.06 \\
\hline Liver & 5 & -3.88 & -2.35 & 1.06 & 0.47 \\
\hline TSP & 5 & 4.06 & 8.07 & 1.09 & 0.10 \\
\hline $\mathrm{HL}$ & 3 & -0.54 & -0.43 & 0.06 & 0.81 \\
\hline \multicolumn{6}{|c|}{$\mathrm{NEAA}, \mathrm{mmol} / \mathrm{h}$} \\
\hline PDV & 5 & 6.88 & 10.00 & 1.05 & 0.05 \\
\hline Liver & 5 & -10.63 & -8.23 & 1.12 & 0.46 \\
\hline TSP & 5 & -3.75 & 1.77 & 1.14 & 0.06 \\
\hline $\mathrm{HL}$ & 3 & -0.26 & -0.29 & 0.18 & 0.98 \\
\hline \multicolumn{6}{|c|}{$\mathrm{BCAA}, \mathrm{mmol} / \mathrm{h}$} \\
\hline PDV & 5 & 4.24 & 5.23 & 0.45 & 0.09 \\
\hline Liver & 5 & -1.03 & -0.11 & 0.54 & 0.34 \\
\hline TSP & 5 & 3.21 & 5.11 & 0.58 & 0.17 \\
\hline HL & 3 & -0.29 & -0.25 & 0.03 & 0.47 \\
\hline \multicolumn{6}{|c|}{ Ammonia-N, mmol/h } \\
\hline PDV & 5 & 11.71 & 11.58 & 0.81 & 0.81 \\
\hline Liver & 5 & -10.60 & -10.84 & 0.77 & 0.55 \\
\hline TSP & 5 & 1.11 & 0.74 & 0.13 & 0.31 \\
\hline HL & 3 & 0.08 & 0.06 & 0.02 & 0.16 \\
\hline \multicolumn{6}{|c|}{ Urea-N, mmol/h } \\
\hline PDV & 5 & -40.69 & -26.72 & 5.01 & 0.13 \\
\hline Liver & 5 & 34.65 & 29.61 & 6.99 & 0.13 \\
\hline TSP & 5 & -6.04 & 2.89 & 6.94 & 0.30 \\
\hline $\mathrm{HL}$ & 3 & -2.78 & 0.56 & 1.07 & 0.19 \\
\hline
\end{tabular}

${ }^{\text {a TAA }}=$ total amino acids $(\mathrm{AA}) ; \mathrm{EAA}$ = essential AA; NEAA = nonessential AA; BCAA = branched-chain AA.

${ }^{\mathrm{b}} \mathrm{PDV}=$ portal drained viscera, TSP $=$ total splanchnic tissues, $\mathrm{HL}=$ hind limb.

'SEM: $\sqrt{(\text { residual mean error of treatments error/n). }}$ RG = ryegrass; $R G+B=$ ryegrass + barley.

\section{Net Portal Appearance of Nitrogenous Compounds}

Total N, Ammonia, Urea, and Total Amino Acids. As previously reviewed by Lapierre and Lobley (2001), a large proportion of $\mathrm{N}$ intake (50 to $60 \%$ ) was utilized by the PDV in ruminants. The $\mathrm{N}$ released by the PDV appeared as TAA (24.2 and $33.3 \%$ of the $\mathrm{N}$ intake for $\mathrm{RG}$ and $\mathrm{RG}+\mathrm{B}$ animals, respectively) or ammonia (19.0 and $15.1 \%$ of the $\mathrm{N}$ intake, respectively).

In general, the NPA of ammonia-N is superior or similar to that of TAA-N in ruminants fed silages or hay (Reynolds et al., 1992). The NPA of ammonia-N is lower when animals are fed concentrate diets (Reynolds et al., 1994; Krehbiel et al., 1992). In the current study, the NPA of ammonia was very low, especially for ruminants fed fresh grass (Journet et al., 1995; DeVisser et al., 1997; Lapierre and Lobley, 2001: 34 to 49\%), but these results are consistent with those obtained in a companion study using growing lambs fed the same basal diet (Savary-Auzeloux et al., 2003). A possible loss of ammonia during grass storage or a possible re- duction in the $\mathrm{N}$ solubility of grass due to the freezing process have been detailed elsewhere (Savary-Auzeloux et al., 2003) and could account for the low ammonia-N NPA with this frozen grass diet.

Barley supplementation had no effects on the NPA of ammonia-N, which is consistent with the absence of alterations in the ammonia- $\mathrm{N}$ concentrations in the ruminal fluid after barley supplementation. These results are similar to those from Lapierre et al. (2000) and Huntington et al. (1996), who did not find any significant effect of the level of intake and of the proportion of concentrate in the diet on the ammonia-N release by the PDV of beef steers. This suggests that in the present experiment, the efficiency of utilization of ruminal degradable $\mathrm{N}$ for microbial protein synthesis was high for both treatments.

Consequently, the increment in the $\mathrm{N}$ intake between the $\mathrm{RG}$ and $\mathrm{RG}+\mathrm{B}$ animals $(+24 \%)$ resulted nearly exclusively in an increased TAA-N NPA. Such an increase is a common feature in the majority of studies where 1) the level of intake was increased (Lapierre et 
Table 5. Effect of barley supplementation on splanchnic and hind limb net fluxes of nonessential amino acids in lambs fed frozen ryegrass

\begin{tabular}{|c|c|c|c|c|c|}
\hline \multirow[b]{2}{*}{ Item } & \multirow[b]{2}{*}{$\mathrm{n}$} & \multicolumn{2}{|c|}{ Treatments } & \multirow[b]{2}{*}{$\mathrm{SEM}^{\mathrm{b}}$} & \multirow[b]{2}{*}{ Probability } \\
\hline & & RG & $R G+B$ & & \\
\hline \multicolumn{6}{|c|}{ Alanine, $\mathrm{mmol} / \mathrm{h}$} \\
\hline $\mathrm{PDV}^{\mathrm{a}}$ & 5 & 2.49 & 3.31 & 0.26 & 0.10 \\
\hline Liver & 5 & -2.97 & -4.29 & 0.30 & 0.05 \\
\hline TSP & 5 & -0.49 & -0.99 & 0.12 & 0.02 \\
\hline $\mathrm{HL}$ & 3 & -0.02 & -0.05 & 0.05 & 0.69 \\
\hline \multicolumn{6}{|c|}{ Aminobutyric acid, $\mathrm{mmol} / \mathrm{h}$} \\
\hline PDV & 5 & -0.11 & 0.09 & 0.09 & 0.11 \\
\hline Liver & 5 & -0.10 & -0.03 & 0.06 & 0.77 \\
\hline TSP & 5 & -0.20 & 0.06 & 0.09 & 0.04 \\
\hline HL & 3 & -0.01 & -0.01 & 0.00 & 0.93 \\
\hline \multicolumn{6}{|c|}{ Arginine, $\mathrm{mmol} / \mathrm{h}$} \\
\hline PDV & 5 & -0.27 & 0.74 & 0.24 & 0.03 \\
\hline Liver & 5 & -0.31 & -0.45 & 0.27 & 0.74 \\
\hline TSP & 5 & -0.58 & 0.28 & 0.19 & 0.05 \\
\hline $\mathrm{HL}$ & 3 & -0.05 & -0.01 & 0.03 & 0.64 \\
\hline \multicolumn{6}{|c|}{ Asx (Asparagine + Aspartate $), \mathrm{mmol} / \mathrm{h}$} \\
\hline PDV & 5 & 0.87 & 1.07 & 0.16 & 0.41 \\
\hline Liver & 5 & -1.14 & -0.94 & 0.12 & 0.01 \\
\hline TSP & 5 & -0.27 & 0.14 & 0.12 & 0.13 \\
\hline HL & 3 & -0.06 & -0.04 & 0.01 & 0.03 \\
\hline \multicolumn{6}{|c|}{ Citrulline, $\mathrm{mmol} / \mathrm{h}$} \\
\hline PDV & 5 & 0.32 & 1.13 & 0.31 & 0.01 \\
\hline Liver & 5 & 0.09 & -0.12 & 0.18 & 0.57 \\
\hline TSP & 5 & 0.41 & 1.01 & 0.21 & 0.16 \\
\hline $\mathrm{HL}$ & 3 & 0.02 & -0.02 & 0.02 & 0.75 \\
\hline \multicolumn{6}{|c|}{ Cystathionine, $\mathrm{mmol} / \mathrm{h}$} \\
\hline PDV & 5 & 0.00 & -0.01 & 0.01 & 0.43 \\
\hline Liver & 5 & -0.01 & 0.00 & 0.00 & 0.23 \\
\hline TSP & 5 & -0.01 & -0.01 & 0.01 & 0.61 \\
\hline HL & 3 & 0.00 & 0.00 & 0.00 & 0.95 \\
\hline \multicolumn{6}{|c|}{ Glycine, $\mathrm{mmol} / \mathrm{h}$} \\
\hline PDV & 5 & 2.52 & 3.39 & 0.25 & 0.01 \\
\hline Liver & 5 & -4.38 & -3.63 & 0.45 & 0.55 \\
\hline TSP & 5 & -1.86 & -0.24 & 0.45 & 0.17 \\
\hline $\mathrm{HL}$ & 3 & 0.03 & 0.14 & 0.07 & 0.01 \\
\hline \multicolumn{6}{|c|}{ Glx (Glutamine + Glutamate), $\mathrm{mmol} / \mathrm{h}$} \\
\hline PDV & 5 & -1.29 & -1.98 & 0.41 & 0.04 \\
\hline Liver & 5 & 1.29 & 3.97 & 0.62 & 0.10 \\
\hline TSP & 5 & 0.01 & 1.99 & 0.59 & 0.17 \\
\hline HL & 3 & 0.03 & -0.21 & 0.10 & 0.55 \\
\hline \multicolumn{6}{|c|}{ Hydroxyproline, $\mathrm{mmol} / \mathrm{h}$} \\
\hline PDV & 5 & -0.08 & 0.09 & 0.05 & 0.04 \\
\hline Liver & 5 & -0.03 & -0.21 & 0.05 & 0.21 \\
\hline TSP & 5 & -0.11 & -0.12 & 0.05 & 0.87 \\
\hline HL & 3 & 0.02 & 0.02 & 0.01 & 0.34 \\
\hline \multicolumn{6}{|c|}{ Ornithine, $\mathrm{mmol} / \mathrm{h}$} \\
\hline PDV & 5 & 0.11 & 0.56 & 0.09 & 0.05 \\
\hline Liver & 5 & 0.55 & 0.42 & 0.14 & 0.45 \\
\hline TSP & 5 & 0.66 & 0.98 & 0.13 & 0.12 \\
\hline HL & 3 & -0.03 & -0.04 & 0.00 & 0.70 \\
\hline Proline & & & & & \\
\hline PDV & 5 & 0.44 & 0.71 & 0.09 & 0.19 \\
\hline Liver & 5 & -0.30 & -0.25 & 0.09 & 0.89 \\
\hline TSP & 5 & 0.14 & 0.47 & 0.09 & 0.29 \\
\hline HL & 3 & -0.03 & -0.01 & 0.01 & 0.38 \\
\hline Serine, & & & & & \\
\hline PDV & 5 & 1.32 & 1.72 & 0.17 & 0.16 \\
\hline Liver & 5 & -1.71 & -1.55 & 0.19 & 0.72 \\
\hline TSP & 5 & -0.39 & 0.17 & 0.18 & 0.05 \\
\hline $\mathrm{HL}$ & 3 & -0.14 & -0.13 & 0.02 & 0.85 \\
\hline & & & & & Continued \\
\hline
\end{tabular}


Table 5 Continued. Effect of barley supplementation on splanchnic and hind limb net fluxes of nonessential amino acids in lambs fed frozen ryegrass

\begin{tabular}{|c|c|c|c|c|c|}
\hline \multirow[b]{2}{*}{ Item } & \multirow[b]{2}{*}{$\mathrm{n}$} & \multicolumn{2}{|c|}{ Treatments } & \multirow[b]{2}{*}{$\mathrm{SEM}^{\mathrm{b}}$} & \multirow[b]{2}{*}{ Probability } \\
\hline & & RG & $R G+B$ & & \\
\hline \multicolumn{6}{|c|}{ Taurine, $\mathrm{mmol} / \mathrm{h}$} \\
\hline PDV & 5 & 0.19 & 0.52 & 0.06 & 0.02 \\
\hline Liver & 5 & -0.42 & -0.05 & 0.11 & 0.15 \\
\hline TSP & 5 & -0.23 & 0.47 & 0.15 & 0.02 \\
\hline $\mathrm{HL}$ & 3 & -0.02 & 0.03 & 0.01 & 0.02 \\
\hline \multicolumn{6}{|c|}{ Tyrosine, $\mathrm{mmol} / \mathrm{h}$} \\
\hline PDV & 5 & 0.80 & 1.04 & 0.12 & 0.07 \\
\hline Liver & 5 & -1.10 & -1.10 & 0.13 & 0.86 \\
\hline TSP & 5 & -0.30 & -0.05 & 0.07 & 0.10 \\
\hline HL & 3 & -0.03 & 0.01 & 0.01 & 0.33 \\
\hline
\end{tabular}

${ }^{\text {apDV }}=$ portal drained viscera, TSP $=$ total splanchnic tissues, $\mathrm{HL}=$ hind limb.

${ }^{\mathrm{b}} \mathrm{SEM}=\sqrt{(\text { residual mean error of treatments error/n). }} \mathrm{RG}=$ ryegrass; $\mathrm{RG}+\mathrm{B}=$ ryegrass + barley.

al., 2000; Reynolds et al., 1991a), 2) some additional casein was infused in the abomasum (Krehbiel and Ferrell, 1999, Guerino et al., 1991), and 3) urea (Krehbiel and Ferrell, 1999; Ferrell et al., 1999) or soybean meal (SBM) (Krehbiel et al., 1998; Ferrell et al., 1999) were added in the diet. Energy supplementation alone is less efficient in improving the NPA of N as AA-N (Ferrell et al., 1999; Seal and Parker, 1996; Savary-Auzeloux et al., 2003). The nature of the basal diet seems also to be important. Recent results from Ferrell et al. (1999 and 2001) showed that when high-concentrate or poorquality forage diets are supplemented with an equal amount of $\mathrm{N}$ as SBM or urea, the increase in $\alpha$-amino N NPA was lower with a high-concentrate diet $(+14 \%$ and $+29 \%$ with urea and SBM supplements, respectively) than with a low-quality forage diet $(+120 \%$ and $117 \%$, respectively). Compiling these studies suggests that the effects of supplementation on the incremental NPA of TAA are primarily dependent on the digestive mechanisms in the rumen (responsible for an efficient $\mathrm{N}$ utilization and an optimized microbial protein synthesis). This hypothesis is supported by the fact that nearly $100 \%$ (Krehbiel and Ferrell, 1999) or above 100\% (Bruckentahl et al., 1997) of supplementary dietary $\mathrm{N}$ (as urea and/or casein) was recovered in the portal vein as TAA-N, especially when the requirements of the PDV tissues for TAA are met to a large extent by the basal diet. The lower recovery rates obtained in our experiment suggests (as explained by MacRae et al., 1997a, b; Krehbiel and Ferrell, 1999) either that some of the AA-N absorption occurs as peptides (not quantified here but that can represent up to $20 \%$ of the PDV N absorption; Remond et al, 2000; Seal and Parker, 1996) or some additional TAA utilization by the intestinal mucosa (one-third of the dietary intake of EAA is consumed in first-pass metabolism by the intestine for catabolism within the mucosal cells and to a lesser extent for incorporation into mucosal proteins (Stoll et al., 1998).

Individual Amino Acids. The increase in the NPA of TAA is in general associated with an increase in the arterial concentrations of a majority of EAA (Lapierre et al., 2000). This was not the case in our experiment, probably because the increase in dietary $\mathrm{N}$ supply was not important enough to induce significant changes at the arterial level. No satisfactory explanation could be found to understand the decrease in valine and citrulline concentrations in the artery (as well as in some other vessels).

Expressed in grams of N, the NPA of EAA and NEAA amounted to 3.25 and $1.80 \mathrm{~g} / \mathrm{d}$ in the $\mathrm{RG}$ animals, whereas these values increased up to 4.32 and 4.28 in $\mathrm{RG}+\mathrm{B}$ animals. Consequently, when $\mathrm{N}$ intake increased by $24 \%$ with barley supplementation, the NPA increased by $33 \%$ for EAA and $132 \%$ for NEAA. With both treatments, more than half of the NPA of TAA was as EAA (64\% and 50\% in RG and RG + B animals, respectively). These values are consistent with those from the literature that range from about $40 \%$ in a majority of studies (Lapierre et al., 2000) up to $75 \%$ (Huntington and Prior, 1985; Seal et al., 1992). The EAA/TAA ratio remains generally stable with intake (Lapierre et al., 2000).

Barley supplementation allowed an increase in the NPA of EAA. These results are consistent with those previously found by MacRae et al. (1997), Lapierre et al. (2000), and Krehbiel and Ferrell (1999), where the NPA of TAA and EAA were increased with intake. A comparison of the AA appearing in the portal vein for the RG and $R G+B$ animals with the composition of the ruminal microbial proteins (Storm and Orskov, 1983) was made, and the values were normalized relative to leucine (data not shown). The AA profile of EAA was in agreement with that reported for the ruminal microbial proteins (Lobley et al., 1996; Van der Walt, 1993) when the animals were fed ryegrass alone or when they were supplemented with barley.

Concerning the NEAA, a decreased utilization of the NEAA (except for glx) for energy purposes at PDV level may have occurred with barley supplementation because the increase in the NPA of NEAA was higher 
Table 6. Effect of barley supplementation on splanchnic and hind limb net fluxes of essential amino acids in lambs fed frozen ryegrass

\begin{tabular}{|c|c|c|c|c|c|}
\hline \multirow[b]{2}{*}{ Item } & \multirow[b]{2}{*}{$\mathrm{n}$} & \multicolumn{2}{|c|}{ Treatments } & \multirow[b]{2}{*}{$\mathrm{SEM}^{\mathrm{b}}$} & \multirow[b]{2}{*}{ Probability } \\
\hline & & RG & $\mathrm{RG}+\mathrm{B}$ & & \\
\hline \multicolumn{6}{|c|}{ Histidine, $\mathrm{mmol} / \mathrm{h}$} \\
\hline $\mathrm{PDV}^{\mathrm{a}}$ & 5 & 0.08 & 0.24 & 0.05 & 0.12 \\
\hline Liver & 5 & -0.25 & -0.06 & 0.07 & 0.02 \\
\hline TSP & 5 & -0.17 & 0.18 & 0.08 & 0.01 \\
\hline HL & 3 & -0.02 & 0.00 & 0.01 & 0.80 \\
\hline \multicolumn{6}{|c|}{ Isoleucine, $\mathrm{mmol} / \mathrm{h}$} \\
\hline PDV & 5 & 1.29 & 1.70 & 0.13 & 0.05 \\
\hline Liver & 5 & -0.22 & 0.01 & 0.15 & 0.46 \\
\hline TSP & 5 & 1.07 & 1.72 & 0.18 & 0.13 \\
\hline $\mathrm{HL}$ & 3 & -0.10 & -0.07 & 0.01 & 0.17 \\
\hline \multicolumn{6}{|c|}{ Leucine, $\mathrm{mmol} / \mathrm{h}$} \\
\hline PDV & 5 & 1.74 & 2.04 & 0.15 & 0.45 \\
\hline Liver & 5 & -0.39 & -0.18 & 0.19 & 0.62 \\
\hline TSP & 5 & 1.36 & 1.86 & 0.21 & 0.40 \\
\hline $\mathrm{HL}$ & 3 & -0.11 & -0.08 & 0.01 & 0.04 \\
\hline \multicolumn{6}{|c|}{ Lysine, $\mathrm{mmol} / \mathrm{h}$} \\
\hline $\mathrm{PDV}$ & 5 & 1.55 & 1.95 & 0.20 & 0.06 \\
\hline Liver & 5 & -0.52 & -0.53 & 0.18 & 0.94 \\
\hline TSP & 5 & 1.03 & 1.42 & 0.24 & 0.55 \\
\hline HL & 3 & -0.10 & -0.11 & 0.02 & 0.41 \\
\hline \multicolumn{6}{|c|}{ Methionine, $\mathrm{mmol} / \mathrm{h}$} \\
\hline PDV & 5 & 0.41 & 0.51 & 0.05 & 0.24 \\
\hline Liver & 5 & -0.29 & -0.19 & 0.04 & 0.25 \\
\hline TSP & 5 & 0.12 & 0.32 & 0.05 & 0.01 \\
\hline $\mathrm{HL}$ & 3 & -0.01 & -0.00 & 0.00 & 0.37 \\
\hline \multicolumn{6}{|c|}{ Phenylalanine, $\mathrm{mmol} / \mathrm{h}$} \\
\hline PDV & 5 & 1.13 & 1.16 & 0.09 & 0.88 \\
\hline Liver & 5 & -1.36 & -1.10 & 0.09 & 0.14 \\
\hline TSP & 5 & -0.24 & 0.07 & 0.08 & 0.13 \\
\hline $\mathrm{HL}$ & 3 & -0.03 & -0.02 & 0.00 & 0.58 \\
\hline \multicolumn{6}{|c|}{ Threonine, $\mathrm{mmol} / \mathrm{h}$} \\
\hline PDV & 5 & 0.53 & 1.33 & 0.37 & 0.03 \\
\hline Liver & 5 & -0.43 & -0.36 & 0.27 & 0.91 \\
\hline TSP & 5 & 0.10 & 0.97 & 0.32 & 0.14 \\
\hline HL & 3 & -0.09 & -0.05 & 0.02 & 0.69 \\
\hline \multicolumn{6}{|c|}{ Valine, $\mathrm{mmol} / \mathrm{h}$} \\
\hline PDV & 5 & 1.21 & 1.48 & 0.21 & 0.35 \\
\hline Liver & 5 & -0.43 & 0.05 & 0.23 & 0.16 \\
\hline TSP & 5 & 0.79 & 1.53 & 0.22 & 0.17 \\
\hline HL & 3 & -0.09 & -0.10 & 0.02 & 0.42 \\
\hline
\end{tabular}

${ }^{\text {apDV }}=$ portal drained viscera, $\mathrm{TSP}=$ total splanchnic tissues, $\mathrm{HL}=$ hind limb.

${ }^{\mathrm{b}} \mathrm{SEM}=\sqrt{(\text { residual mean error of treatments error/n). }} \mathrm{RG}=$ ryegrass; $\mathrm{RG}+\mathrm{B}=$ ryegrass + barley.

than that of EAA. A probable increased utilization of acetate by the PDV in those animals (Majdoub et al., 2002) could have spared some NEAA. Glutamine + glutamate were the only NEAA whose net utilization by the PDV increased by $53 \%$ in our study $(P<0.05)$. Glutamine + glutamate are known to act as an oxidative substrate for the small intestine, and a net utilization of glx by the digestive tract is commonly observed in the literature with various diets (Krehbiel and Ferrell, 1999; Lapierre et al., 2000).

Net Hepatic and Splanchnic Fluxes of Nitrogenous Compounds

Total N, Ammonia, Urea, and Total Amino Acids. On the contrary to the PDV, the liver is a net consumer of
TAA. Indeed, it synthesizes endogenous and exported proteins and utilizes the AA for energetic purposes or urea metabolism (Van Der Walt, 1993). No significant effects of barley supplementation could be demonstrated in the present experiment on net hepatic TAA, EAA, NEAA, and BCAA uptake even if their afferent flows were markedly increased $(P<0.05)$. The fact that the supplementation applied increased both the energy and $\mathrm{N}$ intakes seemed to markedly influence the metabolic fate of the AA in the liver. Indeed, when a N supplementation was applied as casein or ruminally undegradable protein (Guerino et al., 1991; Bruckental et al., 1997; Ferrell et al., 2001), as AA infused intramesenterally (Lobley et al., 2001) or as soybean meal (Krehbiel et al., 1998; Ferrell et al., 2001), the increased 
NPA of AA was followed by an increased net AA uptake by the liver. This was also the case when energy was supplemented alone (Ferrell et al., 1999; Savary-Auzeloux et al., 2003). In accordance with our present results, this is not the case when energy and $\mathrm{N}$ were supplemented together (Lapierre et al., 2000; Taniguchi et al., 1995; Huntington et al., 1996) or when the demand of the peripheral tissues for AA was increased by growth hormone-releasing factor or somatotropin (Reynolds et al., 1992; Bruckental et al., 1997). However, this clear picture would need to be further confirmed since Reynolds et al. (1991) found an increased net AA-N uptake by the liver when increasing the level of intake in heifers. It is probable that the liver does not respond linearly to a change in the plane of feeding because the levels of intake studied by Reynolds et al. (1991) (between 1.4 and $2 \times$ maintenance $[\mathbf{M}]$ requirements) were globally higher than those studied by Lapierre et al $(2000)(0.6$ to $1.7 \times \mathrm{M})$.

Ureagenesis for ammonia- $\mathrm{N}$ disposal is an important function of the liver. Urea-N released by the liver represented, respectively, 130 and $80 \%$ of the ammonia-N + TAA-N liver uptake. These values are higher than those observed by Krehbiel et al. (1998) (56 to 100\%) or Kreikemeier et al. (1993) (42 to 63\%) in sheep but consistent with results obtained in beef cattle (110 to $130 \%$ ) (Reynolds et al., 1990; Reynolds and Tyrrell, 1991). These variable apparent contributions of ammonia-N and TAA-N to ureagenesis can arise, as discussed by Krehbiel et al. (1998) and Kreikemeier et al. (1993), from the fact that the $\mathrm{N}$ balance in the liver is not entirely assessed. Indeed, the liver synthesizes endogenous but also exported proteins (such as albumin, fibrinogen, acute-phase proteins). Endogenous and exported liver proteins are probably regulated differently by intake. As for endogenous liver proteins, intake does not seem to influence their synthesis rate whereas it might reduce their degradation rate (Connell et al., 1997). As for exported proteins (especially albumin), intake would increase their synthesis (Connell et al., 1997). Whether the present experimental treatment could have modified endogenous or exported liver proteins is unclear because no significant alteration in the net TAA net uptake by the liver could be demonstrated in the RG + B animals compared to the RG animals.

Quantitatively, net urea release by the liver was not altered by barley supplementation, which was consistent with results from Lobley et al. (1996) in sheep fed grass pellets supplemented or not with barley. However, other studies have shown an increased urea production with intake (Sarraseca et al., 1998). Our results are yet coherent with the low NPA of ammonia-N and its almost complete uptake by the liver (Lapierre and Lobley, 2001). The urea produced is then partly recycled into the rumen and reused for microbial protein synthesis. In the present experiment, the urea-N removal by the PDV represented, respectively, 117 and $90 \%$ of the urea-N released by the liver as well as 66 and $35 \%$ of the $\mathrm{N}$ intake for $\mathrm{RG}$ and $\mathrm{RG}+\mathrm{B}$ animals, respectively.
No treatment effect could be detected, which is consistent with the fact that a concomitant increase in $\mathrm{N}$ and energy supply in the diet (Lapierre and Lobley, 2001) is less effective for inducing alteration in urea recycling than energy alone (Savary-Auzeloux et al., 2003).

Individual Amino Acids. Taken individually and mirroring what has been previously noted for TAA, EAA, NEAA, and BCAA, no significant effects of barley supplementation could be underlined on the net hepatic uptake of most specific AA. Only a few NEAA (alanine, asx, and glx) and one EAA (histidine) showed significant changes in their net hepatic uptakes.

Alanine is one of the major AA used for gluconeogenesis in the liver (Van Der Walt, 1993). Barley supplementation induced an increased alanine utilization by the liver: the potential contribution of alanine to net hepatic glucose release shifted from 4.8 to $6.3 \%$ despite the fact that net hepatic glucose release was not altered by treatment (Majdoub et al., 2002). Similar increases in net hepatic alanine uptake were demonstrated in beef steers supplemented with casein (Guerino et al., 1991) or receiving higher levels of intake (Reynolds et al., 1991; Lapierre et al., 2000). They paralleled an increased NPA of alanine. In the present experiment, the impact of an increased alanine uptake on liver metabolism is probably limited because the net hepatic uptake of another gluconeogenic precursor, glycine (which plays other important roles in the liver, such as the synthesis of nucleic acids, bile salts, glutathione, and serine) was not altered by barley supplementation and its potential contribution to net glucose release averaged, respectively, 4.8 and $3.5 \%$.

The tendency for an increased hepatic release of glx is difficult to interpret because glutamine is generally taken up in great amounts by the liver (as a glucose precursor; Bergman and Pell, 1984). However, in excess of glutamine uptake, glutamate was released by the liver (Bruckental et al., 1997; Lapierre et al., 2001). Because in our study barley supplementation induced an increased release of glx by the PDV, an increased supply of glutamine could have occurred, leading to an increased glutamate net hepatic release.

As a result of a higher NPA of AA associated with minor changes in hepatic AA uptake, the net splanchnic flux of TAA, EAA, and NEAA tended to be increased by barley supplementation. With barley supplementation, $\mathrm{N}$ intake increased by $5 \mathrm{~g}$ of $\mathrm{N} / \mathrm{d}$, and net splanchnic release increased by $4.63 \mathrm{~g}$ of N/d. Consequently, the additional dietary $\mathrm{N}$ supply was nearly exclusively available to peripheral tissues as AA-N. Previous studies also showed that increased intake led to the same increase in AA supply to peripheral tissues (Lapierre et al., 2000; Reynolds et al., 1991). In contrast, when N (Bruckental et al., 1997; Ferrell et al., 2001; Guerino et al., 1991) or energy alone (Savary-Auzeloux et al., 2003) were supplemented, no strong effects could be underlined on the net splanchnic release of AA-N. 
Utilization of Nitrogenous Compounds by the Hind Limb

Before any interpretation of data obtained at the hind limb level, it is important to underline that only three animals had remained functional at the hind limb level because of loss of the iliac vein catheter patency.

It is common knowledge that increasing the level of intake or applying a concentrate supplementation induced in bovines or ovines an increased $\mathrm{N}$ retention in muscle (Moloney, 1998; Abdul-Razzaq and Bickerstaffe, 1989) as a result of a stimulation of protein synthesis (Harris et al., 1992; Lobley et al., 1992; Lobley et al., 2000). These effects are partly mediated by insulin. In the present experiment, although the insulin (Majdoub et al., 2002) and the AA supply to the peripheral tissues increased after barley supplementation, no effects could be demonstrated on hind limb $\mathrm{N}$ uptake. A few AA showed an altered net hind limb balance but these balances are too close to zero to be interpreted with great certainty.

\section{Implications}

The present results, together with those of a companion paper, show the crucial role of the portal-drained viscera and of the liver in the quantity and quality of nutrients supplied to peripheral tissues. In this study, barley supplementation of a diet based on frozen ryegrass (where nitrogen can be limiting) was very efficient for inducing an increase in the splanchnic release of amino acids to the peripheral tissues. This was not the case when energy alone (such as propionate) was supplemented. More generally, the fate of amino acids depends on the nitrogen/energy balance in both basal and supplemented diets, the overall plane of feeding, and also on the age of the animals, which can all be crucial in the establishment of equilibrium between the splanchnic and the peripheral tissues, such as muscle.

\section{Literature Cited}

Abdul-Razzaq, H. A., and R. Bickerstaffe. 1989. The influence of rumen volatile fatty acids on protein metabolism in growing lambs. Br. J. Nutr. 62:297-310.

Barnes, R. J., R. S. Comline, and A. Dobson. 1986. The control of splanchnic blood flow. Page 41 in Control of Digestion and Metabolism in Ruminants. L. P. Milligan, W. L. Grovum, and A. Dobson, ed. Prentice Hall, Englewood Cliffs, NJ.

Bergman, E. N., and J. M. Pell. 1984. Integration of amino acid metabolism in the ruminant. Pages 613-628 in Herbivore Nutrition in the Subtropics and Tropics. F. M. C. Gilchrist and R. I. Mackie, ed. Science Press, Craighall, Johannesburg, South Africa.

Bergmeyer, H. U. 1985. Ammonia determination. Page 454 in Methods of enzymatic analysis Vol. VIII. H. U. Bergmeyer, J. Bergmeyer, and M. Grassl, ed. Academic Press, London.

Bruckental, I., G. B. Huntington, C. K. Baer, and R. A. Erdman. 1997. The effect of abomasal infusion of casein and recombinant somatotropin hormone injection on nitrogen balance and amino acid fluxes in portal-drained viscera and net hepatic and total splanchnic blood in Holstein steers. J. Anim. Sci. 75:1119-1129.
Connell, A., A. G. Calder, S. E. Anderson, and G. E. Lobley. 1997. Hepatic protein synthesis in the sheep: effect of intake as monitored by use of stable-isotope-labelled glycine, leucine and phenylalanine. Br. J. Nutr. 77:255-271.

DeVisser, H., H. Valk, A. Klop, J. Van der Meulen, J. G. M. Bakker, and G. B. Huntington. 1997. Nutrient fluxes in splanchnic tissue of dairy cows: influence of grass quality. J. Dairy Sci. 80:1666-1673.

Ferrell, C. L., K. K. Kreikemeier, and H. C. Freetly. 1999. The effect of supplemental energy, nitrogen, and protein on feed intake, digestibility, and nitrogen flux across the gut and liver in sheep fed low-quality forage. J. Anim. Sci. 77:3353-3364.

Ferrell, C. L., H. C. Freetly, A. L. Goetsch, and K. K. Kreikemeier. 2001. The effect of dietary nitrogen and protein on feed intake, nutrient digestibility, and nitrogen flux across the portal-drained viscera and liver of sheep consuming high-concentrate diets ad libitum. J. Anim. Sci. 79:1322-1328.

Geay, Y., D. Bauchart, J. F. Hocquette, and J. Culioli. 2001. Effect of nutritional factors on biochemical, structural and metabolic characteristics of muscles in ruminants, consequences on dietetic value and sensorial qualities of meat. Reprod. Nutr. Dev. 41:1-26.

Guerino, F., G. B. Huntington, and R. A. Erdman. 1991. The net portal and hepatic flux of metabolites and oxygen consumption in growing beef steers given postruminal casein. J. Anim. Sci. 69:387-395.

Halbawachs-Strich, M. 1969. Dosage du glucose par la méthode de Bertrand. Page 125 in Analyse Quantitative Chimique. Masson et Cie., Paris.

Harris, P. M., P. A. Skene, V. Buchan, E. Milne, A. G. Calder, S. E. Anderson, A. Connell, and G. E. Lobley. 1992. Effect of food intake on hind limb and whole-body protein metabolism in young growing sheep: chronic studies based on arterio-venous techniques. Br. J. Nutr. 68:389-407.

Huntington, G. B., and R. L. Prior. 1985. Net absorption of amino acids by portal drained viscera and hind half of beef cattle fed a high concentrate diet. J. Anim. Sci. 60:1491-1499.

Huntington, G. B., E. J. Zetina, J. M. Whitt, and W. Potts. 1996. Effects of dietary concentrate level on nutrient absorption, liver metabolism, and urea kinetics of beef steers fed isonitrogenous and isoenergetic diets. J. Anim. Sci. 74:908-916.

Institut National de la Recherche Agronomique. 1978. Tableaux de la valeur nutritive des aliments. Page 519 in Alimentation des Ruminants, INRA Publications. Versailles, France.

Isserty, A., and I. Ortigues. 1994. Methods of analysis relating to blood flow measurement of the viscera and aorta in sheep. Reprod. Nutr. Dev. 34:399-413.

Jouany, J. P. 1982. Volatile fatty acids and alcohol determination in digestive contents, silage juices, bacterial cultures and anaerobic fermentor contents. Sci. Alim. 2:131-144.

Journet, M., G. Huntington, and J. L. Peyraud. 1995. Le bilan des produits terminaux de la digestion. Page 671 in Nutrition des Ruminants Domestiques, Ingestion et Digestion. R. Jarrige, Y. Ruckebush, C. Demarquilly, M. H. Farce, and M. Journet, ed. INRA, Paris, France.

Katz, M. L., and E. N. Bergman. 1969. A method for simultaneous cannulation of the major splanchnic blood vessels in sheep. Am. J. Vet. Res. 30:655-660.

Krehbiel, C. R., D. L. Harmon, and J. E. Schneieder. 1992. Effect of increasing ruminal butyrate on portal and hepatic nutrient flux in steers. J. Anim. Sci. 70:904-914.

Krehbiel, C. R., C. L. Ferrell, and H. C. Freetly. 1998. Effects of frequency of supplementation on dry matter intake and net portal and hepatic flux of nutrients in mature ewes that consume low-quality forage. J. Anim. Sci. 76:2464-2473.

Krehbiel, C. R., and C. L. Ferrell. 1999. Effects of increasing ruminally degraded nitrogen and abomasal casein infusion on net portal flux of nutrients in yearling heifers consuming a high-grain diet. J. Anim. Sci. 77:1295-1305.

Kreikemeier, K. K., H. C. Freetly, and C. L. Ferrell. 1993. The effect of protein supplementation on portal and hepatic nitrogen metabolism in sheep. J. Anim. Sci. 71(Suppl. 1): 82(Abstr.). 
Lapierre, H., J. F. Bernier, P. Dubreuil, C. K. Reynolds, C. Farmer, D. R. Ouellet, and G. E. Lobley. 2000. The effect of feed intake level on splanchnic metabolism in growing beef steers. J. Anim. Sci. 78:1084-1099.

Lapierre, H., and G. E. Lobley. 2001. Nitrogen recycling in the ruminant: A review. J. Dairy Sci. 84:E223-E236.

Lobley, G. E., P. M. Harris, P. A. Skene, D. Brown, E. Milne, A. G. Calder, S. E. Anderson, P. J. Garlick, I. Nevison, and A. Connell. 1992. Responses in tissue protein synthesis to sub- and supramaintenance intake in young growing sheep: comparison of large-dose and continuous-infusion techniques. Br. J. Nutr. 68:373-388

Lobley, G. E., P. J. M. Weijs, A. Connell, A. G. Calder, D. S. Brown, and E. Milne. 1996. The fate of absorbed and exogenous ammonia as influenced by forage or forage-concentrate diets in growing sheep. Br. J. Nutr. 76:231-248.

Lobley, G. E., K. D. Sinclair, C. M. Grant, L. Miller, D. Mantle, A. G. Calder, C. C. Warkup, and C. A. Maltin. 2000.The effects of breed and level of nutrition on whole-body and muscle protein metabolism in pure-bred Aberdeen Angus and Charolais beef steers. Br. J. Nutr. 84:275-284.

Lobley, G. E., D. M. Bremner, and D. S. Brown. 2001. Response in hepatic removal of amino acids by the sheep to short-term infusions of varied amounts of an amino acid mixture into the mesenteric vein. Br. J. Nutr. 85:689-698.

MacRae, J. C., L. A. Bruce, D. S. Brown, D. A. H. Farningham, and M. Franklin. 1997a. Absorption of amino acids from the intestine and their net flux across the mesenteric- and portal-drained viscera of lambs. J. Anim. Sci. 75:3307-3314.

MacRae, J. C., L. A. Bruce, D. S. Brown, and A. G. Calder. 1997b. Amino acid use by the gastrointestinal tract of sheep given lucerne forage. Am. J. Physiol. 273:G1200-G1207.

Majdoub, L., M. Vermorel, and I. Ortigues-Marty. 2003. Ryegrassbased diet and barley supplementation: Partition of energyyielding nutrients among splanchnic tissues and hind limbs in finishing lambs. J. Anim. Sci. 81:1068-1079.

Milano, G. D., A. HotstonMoore, and G. E. Lobley. 2000. Influence of hepatic ammonia removal on ureagenesis, amino acid utilization and energy metabolism in the ovine liver. Br. J. Nutr. 83:307-315.

Moloney, A. P. 1998. Growth and carcass composition in sheep offered isoenergetic rations which resulted in different concentrations of ruminal metabolites. Livest. Prod. Sci. 56:157-164.

Remond, D., L. Bernard, and C. Poncet. 2000. Free and peptide amino acid net flux across the rumen and the mesenteric- and portaldrained viscera of sheep. J. Anim. Sci. 78:1960-1972.

Reynolds, C. K., H. Lapierre, H. F. Tyrrell, T. H. Elsasser, P. Gaudreau, and P. Brazeau. 1990. Growth-hormone releasing factor (GRF) and intake affect net visceral tissue metabolism in growing beef steers. J. Anim. Sci. 67(Suppl. 1):534(Abstr.).
Reynolds, C. K., and H. F. Tyrrell. 1991. Effects of mesenteric vein L-alanine infusion on liver metabolism in beef heifers fed on diets differing in forage: concentrate ratio. Br. J. Nutr. 66:437-450.

Reynolds, C. K., H. F. Tyrrell, and P. J. Reynolds. 1991. Effects of diet forage-to-concentrate ratio and intake on energy metabolism in growing beef heifers: net nutrient metabolism by visceral tissues. J. Nutr. 121:1004-1015.

Reynolds, C. K., H. Lapierre, F. Tyrrell, T. H. Elsasser, R. C. Staples, P. Gaudreau, and P. Brazeau. 1992. Effects of growth hormonereleasing factor and feed intake on energy metabolism in growing beef steers: net nutrient metabolism by portal-drained viscera and liver. J. Anim. Sci. 70:752-763.

Reynolds, C. K., D. L. Harmon, R. L. Prior, and H. F. Tyrrell. 1994. Effects of mesenteric vein L-alanine infusion on liver metabolism of organic acids by beef heifers fed diets differing in forage: concentrate ratio. J. Anim. Sci. 72:3196-3206.

Sarraseca, A., E. Milne, M. J. Metcalf, and G. E. Lobley. 1998. Urea recycling in sheep: effects of intake. Br. J. Nutr. 79:79-88.

Savary-Auzeloux, I., L. Majdoub, N. Le Floc'h, and I. Ortigues-Marty. 2003. Effects of intraruminal propionate supplementation on nitrogen utilization by the portal-drained viscera, the liver and the hindlimb in lambs fed rye-grass. Br. J. Nutr. 90:1-15.

Seal, C. J., D. S. Parker, and P. J. Avery. 1992. The effect of forage and forage-concentrate diets on rumen fermentation and metabolism of nutrients by the mesenteric- and portal-drained viscera in growing steers. Br. J. Nutr. 67:355-370.

Seal, C. J., and D. S. Parker. 1996. Effects if intraruminal propionic acid infusion on metabolism of mesenteric- and portal-drained viscera in growing steers fed a forage diet: II. Ammonia, urea amino acids, and peptides. J. Anim. Sci. 74:245-256.

Stoll, B., J. Henry, P. J. Reeds, H. Yu, F. Jahoor, and D. G. Burrin. 1998. Catabolism dominates the first-pass intestinal metabolism of dietary essential amino acids in milk protein-fed piglets. J. Nutr. 128:606-614.

Storm, E., and E. R. Orskov. 1983. The nutritive value of rumen microorganisms in ruminants 1 . Large-scale isolation and chemical composition of rumen micro-organisms. Br. J. Nutr. 50:463-470.

Taniguchi, K., G. B. Huntington, and B. P. Glenn. 1995. Net nutrient flux by visceral tissues of beef steers given abomasal and ruminal infusions of casein and starch. J. Anim. Sci. 73:236-249.

Van der Walt, J. G. 1993. Nitrogen metabolism in the ruminant liver. Aust. J. Agric. Res. 44:381-403.

Van Eenaeme, C., J. M. Bienfait, O. Lambot and A. Pondant. 1969. Determination automatique de l'ammoniaque dans le liquide du rumen par la méthode de Berthelot adaptée à l'autoanalyseur. Ann. Med. Vet. 7:419-425.

Vérité, R., and C. Demarquilly. 1978. Qualité des matières azotées des aliments pour ruminants. Page 143 in La Vache Laitière. INRA, Versailles, France.

Wessels, R. H., and E. C. Titgemeyer. 1997. Protein requirements of growing steers limit-fed corn-based diets. J. Anim. Sci. 75:3278-3286. 